\title{
Ultrasound-Guided Core Biopsy of the Kidneys in Infants and Children: Kuwait Experience
}

\author{
M. Sheikh a A. Al-Essa ${ }^{\text {b }} \quad$ I. Francis ${ }^{\mathrm{c}}$ \\ Departments of aRadiology, ${ }^{\mathrm{b} P e d i a t r i c s, ~ a n d ~}{ }^{\mathrm{C} P a t h o l o g y}$, Faculty of Medicine, \\ Kuwait University, Kuwait
}

\section{Key Words}

Renal biopsy $\cdot$ Ultrasound $\cdot$ Children

\begin{abstract}
Objective: Ultrasound-guided core renal biopsies were performed in children to describe the accuracy of this technique and compare it with the other techniques. Methods: Forty-six children, aged 9 months to 13 years, were biopsied with $14 \mathrm{G}$ and $18 \mathrm{G}$ Trucut needles, using a real-time ultrasound sector scanner. Results: Adequate biopsy samples were obtained from 88.2 and $86.9 \%$ of the biopsy procedures with $14 \mathrm{G}$ and $18 \mathrm{G}$ Tru-cut needles, respectively. No major complications were encountered. Minor complications were also minimal and seen in only 3 of our patients who were managed conservatively. Conclusion: Ultrasound-guided Trucut renal biopsy is a safe and efficient method for performing renal biopsies in pediatric
\end{abstract}

\begin{tabular}{ll}
\hline KARGER & ( 1999 S. Karger AG, Basel \\
Fax +4161306 1234 34 & \\
$\begin{array}{l}\text { E-Mail karger@karger.ch } \\
\text { www.karger.com }\end{array}$ & $\begin{array}{l}\text { Accessible online at: } \\
\text { http://BioMedNet.com/karger }\end{array}$
\end{tabular}

patients. The use of small needles (18 G) would reduce the complication rate while allowing retrieval of sufficient tissue for histological diagnosis.

\section{Introduction}

Percutaneous renal biopsy was first reported in 1934 [1]. Subsequent developments were mainly focussed on localizing the kidney rather than modifying the method of obtaining the tissue. During the last several years various techniques for localizing the kidney for percutaneous biopsy have been described [2]. We used two sizes of Tru-cut needles, 14 $\mathrm{G}$ and $18 \mathrm{G}$, with ultrasound guidance to perform biopsies in infants and children. Our institution is the only pediatric nephrology referral center for the country serving a population of about half a million children below

Dr. M. Sheikh

Department of Radiology

Faculty of Medicine, Kuwait University

PO Box 24923, 13110 Safat (Kuwait)

Tel./Fax +965 53304 73, E-Mail mehraj@hsc.kuniv.edu.kw 
Table 1. Patients' details

\begin{tabular}{lc}
\hline Age range, years & Patients \\
\hline $0-2$ & 5 \\
$3-6$ & 17 \\
$7-12$ & 16 \\
$13-16$ & 2 \\
\hline Total & 40 \\
\hline
\end{tabular}

Male: $\mathrm{n}=22$; female: $\mathrm{n}=18$.

Table 2. Indications for biopsy

\begin{tabular}{lc}
\hline & Patients \\
\hline SLE & 7 \\
Hematuria + proteinuria & 6 \\
Nephrotic syndrome & 5 \\
Steroid resistance nephrotic syndrome & 11 \\
Steroid-dependent nephrotic syndrome & 7 \\
Acute renal failure & 1 \\
Chronic renal failure & 1 \\
Renal failure + nephrotic syndrome & 1 \\
Hematuria & 1
\end{tabular}

the age of 15 years as per the 1995 census [3]. In this study we describe the accuracy of this technique and compare it with other techniques.

\section{Patients and Methods}

\section{Patients}

During a period of 2 years, from September 1996 to August 1998, 41 ultrasound-guided kidney biopsies were performed on 40 children who were referred from the Nephrology and Pediatric Departments of the Mubarak Al-Kabeer Teaching Hospital Kuwait. These were 22 males and 18 females. Their ages ranged from 9 months to 13 years. Five children were less than 2 years, the youngest being 9 months old. Seventeen chil-
Table 3. Needle type

\begin{tabular}{lcr}
\hline \multirow{2}{*}{$\begin{array}{l}\text { Age range } \\
\text { years }\end{array}$} & \multicolumn{2}{c}{ Needle type } \\
\cline { 2 - 3 } & $14 \mathrm{G}$ & $18 \mathrm{G}$ \\
\hline $0-2$ & 2 & 3 \\
$3-6$ & 7 & 10 \\
$7-12$ & 8 & 8 \\
$13-16$ & 0 & 2 \\
\hline Total & 17 & 23 \\
\hline
\end{tabular}

dren were between 3 and 6 years old, 16 were between 7 and 12 years old and 2 were 13 years old (table 1 ). The indications (table 2) for the biopsy were systemic lupus erythematosus (SLE), 7 cases; microscopic hematuria with proteinuria, 6 cases; gross hematuria alone, 1 case; nephrotic syndrome, 23 cases; and acute renal failure, 3 cases, of which 1 case presented with nephrotic syndrome and renal failure. Biopsies were performed on uncooperative infants and children. Biopsies were not performed in the presence of bleeding diathesis. One patient who had features of a coagulation defect (prolonged prothrombin time and activated partial thromboplastin time) was given fresh frozen plasma infusion and vitamin $\mathrm{K}$ before the biopsy procedure.

\section{Procedure}

The children were made to lie prone with a small bolster under their abdomen to fix the kidneys. Precautions were taken to maintain their airways and breathing, and intravenous sedation was given whenever required. The back was cleaned and draped, and sterile coupling jelly was applied. The kidneys were scanned to ensure that the renal poles were clearly visible. The left lower pole was usually chosen unless contraindicated. After infiltrating the subcutaneous tissues with local anesthetic, Tru-cut biopsy needles with a 3-, 4.5or 6-inch-long cannula, and a $20-\mathrm{mm}$ specimen notch were used (Baxter Tru-cut biopsy needle). The needle has an inner notch component and an outer sheath. The needle tip was advanced under real-time monitoring till it reached the cortex of the kidney. Two cores were usually obtained. The size of the needle was usually selected according to the weight and body size of the child (table 3 ). 
The children were then transferred to the ward on a trolley with instructions to have complete bed rest for $24 \mathrm{~h}$. They were watched for gross and microscopic hematuria, vital signs, and abdominal pain and distension for $24 \mathrm{~h}$. Monitoring was performed initially every $15 \mathrm{~min}$ for $1 \mathrm{~h}$, every $30 \mathrm{~min}$ for $2 \mathrm{~h}$, and then hourly. A repeat ultrasound was done to check for any perirenal hematoma the next day or earlier if indicated by a drop in the hemoglobin level.

\section{Results}

Diagnostically adequate tissue for biopsy was obtained in 40 out of 41 biopsy procedures. In 1 patient the procedure was repeated after 1 week. The total number of glomeruli per biopsy varied from 5 to 41 with the $14 \mathrm{G}$ Tru-cut needle, and 6-20 glomeruli with the $18 \mathrm{G}$ needle. The mean number of glomeruli obtained was 17.3 and 12.8 with $14 \mathrm{G}$ and 18 $\mathrm{G}$ needles, respectively (table 4). Biopsies were sent for light microscopy, electron microscopy and immunofluorescence.

\section{Complications}

There were no major complications and none of the children required hospitalization for biopsy-related complications (table 5). One 3-year-old child had macroscopic hematuria which disappeared in $24 \mathrm{~h}$ and was managed conservatively. No blood transfusions were required. Two patients developed flank pain and ultrasound revealed a small perinephric hematoma. Both abated on conservative management.

\section{Discussion}

Renal biopsy is a difficult procedure in children because of the smaller size of the kidneys and children cannot cooperate with the procedure $[4,5]$. The pediatric kidneys are more mobile compared with the adult kidneys
Table 4. Biopsy results

\begin{tabular}{|c|c|c|}
\hline \multirow[t]{2}{*}{ Histological results } & \multicolumn{2}{|l|}{ Needle type } \\
\hline & $14 \mathrm{G}$ & $18 \mathrm{G}$ \\
\hline \multirow{2}{*}{$\begin{array}{l}\text { Diagnostic biopsy } \\
\text { Nondiagnostic biopsy } \\
\text { (no renal tissue) }\end{array}$} & 17 & 23 \\
\hline & $1^{\mathrm{a}}$ & \\
\hline $\begin{array}{l}\text { Total glomeruli } \\
\text { per biopsy }\end{array}$ & $\begin{array}{l}5-41 \\
\text { (mean 17.3) }\end{array}$ & $\begin{array}{l}6-20 \\
\text { (mean 12.8) }\end{array}$ \\
\hline $\begin{array}{l}\text { More than } 10 \text { glomeruli } \\
\text { per biopsy }\end{array}$ & $\begin{array}{l}88.20 \% \\
(15 / 17)\end{array}$ & $\begin{array}{l}86.90 \% \\
(20 / 23)\end{array}$ \\
\hline a This was successfully & epeated. & \\
\hline
\end{tabular}

Table 5. Complications

\begin{tabular}{lcc}
\hline & $14 \mathrm{G}$ & $18 \mathrm{G}$ \\
\hline Local pain or discomfort & 17 & 11 \\
Macroscopic hematuria & nil & 1 \\
$\begin{array}{l}\text { Perirenal hematoma } \\
\begin{array}{l}\text { Any major complication requiring } \\
\text { treatment/hospitalization }\end{array}\end{array}$ & nil & nil \\
\hline
\end{tabular}

[4]. It is imperatively necessary to have the child immobile during the procedure which can be achieved with sedation or general anesthesia. Clinical complications after renal biopsy include gross hematuria, large hematomas, severe pain, infection and arteriovenous fistulas. Macroscopic hematuria is reported between 7\% [6] and 11-12\% [7, 8]. In our series there was no case of macroscopic hematuria that required treatment or any other major clinical complication. There was no indication of any internal hemorrhage. A small perirenal hematoma was observed in 2 (5\%) of our patients. Other authors [9] also reported a low incidence of this minor complication, though other minor complications 
like local pain or discomfort are not uncommon [6]. In patients with coagulation defects the risk of postbiopsy bleeding can be reduced by fresh frozen plasma infusion and vitamin $\mathrm{K}$.

Various sizes and types of needles have been used by different authors [4, 10, 11] with the aim to minimize bleeding complications. We used $14 \mathrm{G}$ and $18 \mathrm{G}$ Tru-cut needles with exact positioning of the needles under ultrasound guidance and found both equally safe and effective with no major complication. A similar observation has been reported by other authors using needles of identical gauges [5]. The adequacy of the biopsy material also compared favorably with other reports in the literature $[6,7,12]$ regardless of the technique used $[5,13]$.

\section{Conclusion}

We conclude that the use of Tru-cut needles under ultrasound guidance is a safe and an efficient method for performing renal biopsies in pediatric patients. The use of smaller $(18 \mathrm{G})$ needles would reduce the complication rate while allowing the retrieval of sufficient tissue for histological diagnosis.

\section{Acknowledgments}

The authors would like to thank Dr. Carole Palmer for a critical reading of the manuscript, Ms. Sally Roy for her excellent technical assistance and Mr. James D'Almeida for his secretarial help.

\section{References}

1 Ball DP: Needle (aspiration) biopsy. J Tenn Med Assoc 1934;27:203206.

2 Madaio MP: Renal biopsy. Kidney Int 1990;38:529-543.

3 Directory of Civil Information: Population and Labour Force. Kuwait, Public Authority of Civil Information, July 1997.

4 Sahney S, Chandra GM: Renal biopsy in infants and children. Am $\mathrm{J}$ Kidney Dis 1994;23:31-32.

5 Webb NJ, Pereira JK, Chait PG, Geary DF: Renal biopsy in children: Comparison of two techniques. Pediatr Nephrol 1994;8:486-488.
6 Bohlin A, Edstrom S, Almgren B, Jaremko G, Jorulf H: Renal biopsy in children: Indications, technique and efficacy in 119 consecutive cases. Pediatr Nephrol 1995;9:201203.

7 Chan JC, Brewer WH, Still WJ: Renal biopsies under ultrasound guidance: 100 consecutive biopsies in children. J Urol 1983;129:103-107.

8 Sweet M, Brouhard BH, RamirezSejas F, Kalia A, Travis LB: Percutaneous renal biopsy in infants and young children. Clin Nephrol 1986; 96:192-194.

9 Beaman M: How to perform a renal biopsy. Br J Hosp Med 1989;41: 158-160.

10 Poster RB, Jones DB, Spirt BA: Percutaneous pediatric renal biopsy: Use of the biopsy gun. Radiology 1990;176:725-727.
11 Veiga PA, Moxey-Mims MM, Springate JE, Feld LG: A simple method for percutaneous renal biopsy. Child Nephrol Urol 1991;11: 196-198.

12 Cozens NJ, Murchison JT, Allan PL, Winney RJ: Conventional $15 \mathrm{G}$ needle technique for renal biopsy compared with ultrasound-guided spring loaded $18 \mathrm{G}$ needle biopsy. Br J Radiol 1992;65:594-597.

13 Bogan ML, Kopecky KK, Kraft JL, Holladay AO, Leapman SB, Thomalla JV: Needle biopsy of renal grafts: Comparison of two techniques. Radiology 1990;174:273275. 